Tropical Journal of Pharmaceutical Research April 2019; 18 (4): 799-807

ISSN: $1596-5996$ (print); 1596-9827 (electronic)

(c) Pharmacotherapy Group, Faculty of Pharmacy, University of Benin, Benin City, 300001 Nigeria.

\title{
Evaluation of anti-nociceptive, anti-inflammatory and hepatoprotective effects of methanol extract of Mazus pumilus (Burm. f.) Steenis (Mazaceae) herb
}

\author{
Saiqa Ishtiaq*, Ayesha Ilyas', Numera Irshad", Uzma Niaz', Uzma Hanif ${ }^{2}$, \\ Muhammad Shaharyar Khan Afridi ${ }^{1}$, Shabnam Shaheen ${ }^{3}$, Sairah H Kamran ${ }^{1}$ \\ ${ }^{1}$ Punjab University College of Pharmacy, University of the Punjab Allama lqbal Campus, Lahore - 54000, ${ }^{2}$ Department of \\ Botany, Government College University Lahore, ${ }^{3}$ Department of Plant Science, Lahore College for Women University Lahore, \\ Pakistan
}

*For correspondence: Email: saiqa.pharmacy@pu.edu.pk; Tel: +92 300 4399827; Fax: +92-42-99211624

Sent for review: 16 August 2017

Revised accepted: 15 March 2019

\begin{abstract}
Purpose: This study was designed to investigate the anti-nociceptive, anti-inflammatory and hepatoprotective activities of the methanol extract of Mazus pumilus (Mazaceae) herb.

Methods: Anti-nociceptive activity was determined using hot plate, tail flick and acetic acid-induced writing methods. Carrageenan-induced rat paw edema $(0.1 \mathrm{~mL}$ of $1 \%)$ model was used for the assessment of anti-inflammatory activity. The methanol extract was administered orally at three different doses (150, 300 and $600 \mathrm{mg} / \mathrm{kg}$ ) to three separate groups in all the experiments. Diclofenac sodium (50 $\mathrm{mg} / \mathrm{kg}$ ) was used as standard drug while control group received DMSO (1\%, $10 \mathrm{~mL} / \mathrm{kg})$. The hepatocurative effect of methanol extract of M. pumilus $(400 \mathrm{mg} / \mathrm{kg})$ was determined in isoniazid (50 $\mathrm{mg} / \mathrm{kg}$ ) and rifampicin $(100 \mathrm{mg} / \mathrm{kg})$ induced liver injury. Silymarin $(100 \mathrm{mg} / \mathrm{kg})$ was used as standard drug for comparison. The control group received distilled water $(10 \mathrm{~mL} / \mathrm{kg})$. Preliminary phytochemical screening was also carried out.

Results: The methanol extract of $M$. pumilus significantly $(p<0.05)$ augmented latency time and reduced the number of writhes in the pain models at all doses used for the assessment of antinociceptive actions. The anti-inflammatory activity of different doses of extract was evaluated by measuring the reduction in the size of the paw. A significant $(p<0.05)$ hepatocurative effect was observed when administered after anti-tuberculosis drugs. Histopathological analysis of the liver tissues also revealed restored hepatocellular architecture.

Conclusion: The results demonstrate the anti-nociceptive, anti-inflammatory and hepatoprotective effects of the methanol extract of $M$. pumilus, thus substantiating the ethnomedical claims associated with the herb.
\end{abstract}

Keywords: Mazus pumilus, Tong quan cao, Asian Mazus, Anti-nociceptive, Anti-inflammatory, Hepatoprotective

This is an Open Access article that uses a fund-ing model which does not charge readers or their institutions for access and distributed under the terms of the Creative Commons Attribution License (http://creativecommons.org/licenses/by/4.0) and the Budapest Open Access Initiative (http://www.budapestopenaccessinitiative.org/read), which permit unrestricted use, distribution, and reproduction in any medium, provided the original work is properly credited.

Tropical Journal of Pharmaceutical Research is indexed by Science Citation Index (SciSearch), Scopus, International Pharmaceutical Abstract, Chemical Abstracts, Embase, Index Copernicus, EBSCO, African Index Medicus, JournalSeek, Journal Citation Reports/Science Edition, Directory of Open Access Journals (DOAJ), African Journal Online, Bioline International, Open-J-Gate and Pharmacy Abstracts 


\section{INTRODUCTION}

The search for new anti-inflammatory and analgesic compounds has been a priority for researchers in the past few years due to increased burden of inflammatory diseases [1]. According to the WHO survey in various developing countries, 40 to $90 \%$ of the population relies on traditional system of medicines to meet primary healthcare needs [2]. Because of the undesirable impacts of the allopathic medications on liver, the use of natural pharmaceuticals and phytopharmaceuticals has expanded for liver diseases. Another factor for their greater worthiness, is their simple accessibility, monetary and less untoward impacts on human health. However herbal medicines lack evidenced based therapeutic uses [3].

Mazus is a low-growing perennial plant consisting of 30 species. Mazus pumilus, an annual herb belongs to family Mazaceae, also called Asian mazus or Japanese Mazus. It is generally found in damp habitats in lowland or mountain regions of China, Japan, South East Asia, Australia, New Zealand and Punjab region of Pakistan [4]. In Chinese medicine, it is known as "Tong quan cao". The herb is of great significance owing to its diverse therapeutic benefits. As an ethnomedicine, the leaves of herb have been used in epileptic seizures [5]. The herb possesses antimicrobial activity against certain bacteria and fungi [6]. The anticancer activity by the leaf extract of $M$. pumilus on human cell lines have been reported by Priya et al [7]. The herb is likewise accounted to relieve constipation, a stimulator to menstrual flow, a vigor tonic and antipyretic agent. The juice of the herb is used as a remedy for typhoid fever. In an ethnobotanical review, the herb was discovered as fodder for the livestock [8]. The plant extract possess appreciable antioxidant activity, because of which the herb is also mentioned as cardioprotective [9]. Because of the anti-oxidative properties of the herb's extracts, the present investigation was brought up with a target to assess methanol extract of $M$. pumilus herb for the anti-nociceptive, anti-inflammatory and hepatoprotective activities.

\section{EXPERIMENTAL}

\section{Chemicals}

Methanol, Dimethyl sulfoxide (DMSO), Diclofenac $\mathrm{Na}$., distilled water, acetic acid and carrageen, isoniazid (INH), rifampicin (RMP) were procured from Pacific Pharmaceuticals Ltd. (Lahore, Pakistan). Diagnostic kits of alanine transaminase (ALT), aspartate aminotransferase (AST), alkaline phosphatase (ALP), bilirubin and total protein was obtained from Global (London) and silymarin was acquired from Wilson's Healthcare Pakistan. All other reagents were of analytical grade. The reagents used were freshly prepared in Postgraduate Research laboratory of Pharmacognosy, Punjab University College of Pharmacy, University of the Punjab.

\section{Plant material}

The plant was collected from botanical garden of Government College University Lahore and was authenticated by Dr. Uzma Hanif, Assistant Professor, Department of Botany, Government College University Lahore, Pakistan. A specimen of the plant was deposited in herbarium of Government College University Lahore, under voucher No: GC. Herb. Bot. 2270. All plant parts were dried under shade, pulverized and stored in hermetic containers in a dry place.

\section{Animals}

Swiss albino mice and Wistar rats of either sex were purchased from the University of Veterinary and Animal Sciences, Lahore Pakistan. The animals were kept at room temperature $25 \stackrel{\circ}{\circ}$ under $12 \mathrm{~h}$ of dark and light cycles, and fed with standard pelleted diet with water ad libitum. All the protocols of the study were approved by the Animal Ethical Committee of the Punjab University College of Pharmacy, University of the Punjab. A reference number was issued by the departmental ethical committee (no. AEC/PUCP/1042/4313). The Animal Ethical Committee follows the international guidelines of National Institute of Health [10].

\section{Preparation of methanol extract}

The extract was prepared by macerating $500 \mathrm{~g}$ of dried powder of $M$. pumilus in $1500 \mathrm{~mL}$ of methanol for three days in round bottom flask. The extract was filtered using Whatman No. 1 filter paper. The filtrate was evaporated in rotary evaporator and dried below $40^{\circ} \mathrm{C}$.

\section{PHYTOCHEMICAL SCREENING}

The phytochemical analysis was performed according to standard procedures [11].

\section{Study design}

\section{Analgesic activity}

The tests were performed on male mice having weight between $22-35 \mathrm{~g}$. Total twenty five 
animals were utilized for experimentation, partitioned into 5 groups $(n=5)$. All treatments were administered orally and plant extract was dissolved in $1 \%$ DMSO. Group I was administered $1 \%$ DMSO (10 mL/kg, po) as control. Group II was given standard drug, diclofenac sodium (50 mg/kg, po). Groups III, IV and $\mathrm{V}$ were administered 150, 300 and 600 $\mathrm{mg} / \mathrm{kg}$ (po) of methanol extract of $M$. pumilus dissolved in $1 \%$ DMSO, respectively.

\section{Anti-inflammatory activity}

The anti-inflammatory test was carried out on rats of either sex. Twenty five rats weighing between 200 - $335 \mathrm{~g}$, were incorporated in this activity. The animals were divided into five groups $(n=5)$. Plant extract was dissolved in 1 $\%$ DMSO. Group I was labeled as control and administered $1 \%$ DMSO (10 mL/kg, po). Group II was given standard drug diclofenac sodium (50 $\mathrm{mg} / \mathrm{kg}$, po). Groups III, IV and V were administered 150, 300 and $600 \mathrm{mg} / \mathrm{kg}$ (p.o.) of methanol extract of $M$. pumilus dissolved in $1 \%$ DMSO, respectively. All treatments were administered orally.

\section{Hepatoprotective activity}

Hepatoprotective activity was carried out on Wistar rats of either sex. The study was conducted for twenty one days. The weight of the rats included in the study was in the range of 150 - $200 \mathrm{~g}$. Twenty animals were divided into four groups $(n=5)$. Group I was given distilled water $(10 \mathrm{~mL} / \mathrm{kg})$ and labeled as Control. Group II was administered Isoniazid INH (50 mg/kg) and Rifampicin RMP (100 mg/kg). Group III was treated with extract of silymarin $(100 \mathrm{mg} / \mathrm{kg})$, INH (50 mg/kg) and RMP (100 mg/kg). Group IV was treated with $M$. pumilus $(400 \mathrm{mg} / \mathrm{kg})$, INH (50 $\mathrm{mg} / \mathrm{kg})$ and RMP (100 mg/kg). All treatments were administered orally dissolved in distilled water.

\section{Assessment of anti-nociceptive activity}

The anti-nociceptive activity of the methanol extract of $M$. pumilus was determined by three different methods.

\section{Hot plate method}

Animals were subjected to pre-testing on hot plate (Havard apparatus). The temperature of hot plate was set at $55 \pm 0.1{ }^{\circ} \mathrm{C}$. After $30 \mathrm{~min}$ of treatment, the animals were exposed to hot plate and latency time was recorded in seconds. Latency time is the time for which mouse remains on the hot plate without licking or flicking of hind limb or jumping. The animals showing latency time greater than fifteen seconds were not included in the study. To avoid the tissue damage, 30 sec cut-off time was selected for all animals. The latency time for all groups was recorded at $0,0.5,1.0,1.5,2.0,2.5,3.0,3.5,4.0$ and $4.5 \mathrm{~h}$ after drug administration [12].

\section{Tail immersion method}

The animals were placed in upright position to set their tails in hanging position. The tail of each animal was marked up to $5 \mathrm{~cm}$ length and was dipped into a container of hot water. Healthy animals were selected for this experiment who responded within $15 \mathrm{sec}$ to hot water stimulus. Temperature of hot water was about $55 \pm 0.5^{\circ} \mathrm{C}$. Time taken to pull the tail out of hot water called reaction time was measured. The readings were taken at the time interval of $0,0.5,1.0,1.5,2.0$, $2.5,3.0,3.5,4.0$ and $4.5 \mathrm{~h}$ of administration of the test drugs. A cut-off time of $30 \mathrm{sec}$ was considered i.e. time of no response [13].

\section{Acetic acid induced writhing method}

Thirty minutes after the administration of $M$. pumilus extract, each treatment group was intraperitoneally administered acetic acid $(10 \mathrm{~mL} / \mathrm{kg}$ of $0.6 \%$ ). Five min after the acetic acid injection, the number of abdominal constrictions (writhes) were counted for next $10 \mathrm{~min}$ [14].

\section{Determination of anti-inflammatory activity}

\section{Carrageenan-induced rat paw edema}

Thirty minutes after the intra-peritoneal administration of different doses of the methanol extract and standard drug to their relevant groups, carrageenan $(1 \%, 0.1 \mathrm{~mL})$ was injected subcutaneously in the sub plantar tissue of the right hind paw of each rat. Digital vernier caliper was used to measure the inflammation right after the injection of carrageenan and then after the time interval of $0.5,1,2,3$ and $4 \mathrm{~h}$. Percentage (\%) inhibition of edema (E) was calculated using Eq 1.

$E(\%)=\{(A-B) / A\} 100$

where A represents edema volume of control and B paw edema of tested group [15].

\section{Evaluation of hepatoprotective activity}

All the animal groups were subjected to oral administration of respective treatments in distilled water $(10 \mathrm{~mL} / \mathrm{kg})$ for a period of 21 days. At the end of the study, animals were anaesthetized by 
intra-peritoneal administration of $5 \mathrm{~mL} / \mathrm{kg}$ of a solution of $1 \%$ chloralose in $25 \%$ urethane $(w / v)$. Blood samples were drawn from the anaesthetized animals by cardiac puncture in sterile heparinized tubes and allowed to clot for 30 min. Serum was separated from the blood by centrifugation process and used for the assay of serum marker enzymes [16].

\section{Histopathological examination}

Fresh liver tissues (previously trimmed to $7 \mu \mathrm{m}$ thick) were placed in plastic cassettes and immersed in neutral buffered formalin for $24 \mathrm{~h}$. Treated tissues were fixed in paraffin, sectioned, deparaffinized and re-hydrated. The tissues were then stained with eosin and hematoxylin. The structural changes in prepared liver slides were analyzed under microscope [17].

\section{Statistical analysis}

Data are expressed as mean \pm SEM. Statistical analysis was carried out using SPSS 21 and GraphPad Prism 7. Statistical significance of the differences between control and treated groups was calculated using One-way ANOVA with posthoc Tukey's HSD test. $P<0.05$ was considered statistically significant.

\section{RESULTS}

\section{Phytochemical analysis}

Phytochemical screening of methanol extract revealed presence of proteins carbohydrates, saponins, tannins, terpenoids, sterols, glycosides and alkaloids whereas lipids were absent (Table 1).

Table 1: Phytochemical profile of methanol extract of M. pumilus

\begin{tabular}{llc}
\hline Compound group & Test & Result \\
\hline Proteins & Millon's test & + \\
Carbohydrates & Molisch's test & + \\
Saponin & Foam test & + \\
Lipids & Soap formation test & - \\
Tannins & Ferric chloride test & + \\
Terpenoids & Salkowaski test & + \\
Sterols & Salkowaski test & + \\
Glycosides & Keller-killani test & + \\
Flavonoids & Ferric Chloride test & + \\
Alkaloids & Dragendroff's test & + \\
\hline$+=$ present, $-=$ absent &
\end{tabular}

\section{Analgesic activity}

The results of the hot plate test revealed that latency time significantly $(p<0.05)$ increased with $150 \mathrm{mg} / \mathrm{kg}$ as compared to the DMSO $1 \%$ treated group. The effect was significant at all test doses and the maximum effect was observed after $2 \mathrm{~h}$. The most significant increase in latency time was observed with $150 \mathrm{mg} / \mathrm{kg}$ of plant extract (Table 2), $2 \mathrm{~h}$ after the administration of the methanol extract of $M$. pumilus. Maximum analgesic effect of diclofenac sodium was also observed at $2 \mathrm{~h}$. Non-significant results were obtained with 300 and $600 \mathrm{mg} / \mathrm{kg}$ dose as presented in Table 2.

The analgesic effect of the plant extract was significant $(p<0.05)$ in tail flick test. The maximum analgesic effect was noticed $4 \mathrm{~h}$ after the administration of $150 \mathrm{mg} / \mathrm{kg}(60.88 \mathrm{sec} \pm 4$ .73) and $600 \mathrm{mg} / \mathrm{kg}(111.0 \mathrm{sec} \pm 3.62)$ respectively and at $2.5 \mathrm{~h}$ with $300 \mathrm{mg} / \mathrm{kg}(48.4$ $\mathrm{sec} \pm 3.86)$. The standard drug diclofenac sodium (50 mg/kg body weight) induced a significant $(p<0.05)$ decrease in the tail flick response at $2 \mathrm{~h}$ when compared to control untreated group as presented in Table 3.

The methanol extract of $M$. pumilus at different $(150,300$, and $600 \mathrm{mg} / \mathrm{kg}$ ) doses significantly ( $p$ $<0.05)$ reduced the number of abdominal constrictions (writhing) induced in mice by acetic acid $0.6 \%$ i.p. The results showed that the antinociceptive activity increased with increasing the dose of the extract (150, 300 and $600 \mathrm{mg} / \mathrm{kg}$ ). This dose-dependent analgesic effect reached a maximum inhibition of $59.16 \%$ at the dose of $600 \mathrm{mg} / \mathrm{kg}$. The standard drug, diclofenac sodium $(50 \mathrm{mg} / \mathrm{kg})$ exerted a significant analgesic effect, with percentage inhibition of $80.89 \%$ (Table 4). M. pumilus extract and diclofenac sodium showed significant $(p<0.05)$ reduction of pain in comparison with control group given DMSO and $0.6 \%$ acetic acid (Table 4).

\section{Anti-inflammatory activity}

The methanol extract of $M$. pumilus at all doses showed significant $(p<0.05)$ reduction in paw edema at first, second, third and fourth hour as compared to reference drug diclofenac sodium. The reduction in paw size shows reduced inflammation as presented in Table 5 at different time intervals. Diclofenac $\mathrm{Na}(50 \mathrm{mg} / \mathrm{kg})$ at $4^{\text {th }} \mathrm{h}$ showed significant and maximum reduction of paw edema in comparison with the control group at $4^{\text {th }}$ hour. The reduction in size of paw in extract treated group at different time intervals is comparable to Diclofenac $\mathrm{Na}$ that showed decrease in paw edema starting from $1 \mathrm{~h}$ after the administration of drug for up to $4 \mathrm{~h}$. The methanol extract at the dose of $150 \mathrm{mg} / \mathrm{kg}$ exhibited a significant anti-inflammatory activity $0.5 \mathrm{~h}$ after the injection of carrageenan and was 
Table 2: Anti-nociceptive effect of methanol extract of $M$. pumulis herb by hot plate method in mice

\begin{tabular}{|c|c|c|c|c|c|c|c|c|c|c|}
\hline Treatment & $\begin{array}{l}\text { Dose } \\
\mathrm{mg} / \mathrm{kg}\end{array}$ & Oh & $0.5 \mathrm{~h}$ & $1 \mathrm{~h}$ & $1.5 \mathrm{~h}$ & $2 \mathrm{~h}$ & $2.5 \mathrm{~h}$ & $3 \mathrm{~h}$ & $3.5 \mathrm{~h}$ & $4 \mathrm{~h}$ \\
\hline \multirow[t]{3}{*}{ DMSO 1\% } & $10 \mathrm{ml}$ & $12.79 \pm 0.90$ & $13.16 \pm 0.90$ & $13.35 \pm 0.89$ & $15.65 \pm 0.78$ & $16.59 \pm 0.75$ & $17.34 \pm 0.58$ & $17.60 \pm 0.67$ & $17.19 \pm 0.66$ & $16.77 \pm 0.65$ \\
\hline & 150 & $15.90^{*} \pm 0.59$ & $17.38^{\star} \pm 0.55$ & $30.50^{*} \pm 1.54$ & $46.46^{\star} \pm 6.75$ & $81.24^{*} \pm 6.99$ & 20.15 & $22.85 \pm 1.02$ & 18.7 & 18. \\
\hline & 300 & $15.84^{*} \pm 0.56$ & $31.23^{*} \pm 1.31$ & $35.10^{*} \pm 1.61$ & $34.03 \pm 1.46$ & $47.68 \pm 2.30$ & $39.53^{*} \pm 2.10$ & $37.01^{*} \pm 2.23$ & $29.02^{*} \pm 1.30$ & $23.95^{\star} \pm 1.13$ \\
\hline & 600 & $16.25^{\star} \pm 0.55$ & $21.85^{\star} \pm 0.85$ & $25.17 \pm 1.11$ & $24.45 \pm 1.76$ & $0 \pm 1.82$ & $18.32 \pm 0.94$ & $18.49 \pm 1.02$ & $15.85^{\star} \pm 0.95$ & $14.66^{*} \pm 0.98$ \\
\hline Diclofenac $\mathrm{Na}$ & 50 & $16.60^{\star} \pm 0.54$ & $17.77^{*} \pm 0.64$ & $17.91 \pm 0.62$ & $17.54 \pm 0.80$ & $20.92 \pm 0.91$ & $19.74 \pm 0.81$ & $18.66 \pm 0.93$ & $16.77 \pm 0.79$ & $14.11 \pm 0.60$ \\
\hline
\end{tabular}

All the results are presented in seconds and values are expressed as mean \pm SEM $(n=5)$. The extract and Diclofenac Na treated groups were compared with $1 \%$ DMSOtreated group using one-way ANOVA followed by Tukey's test; * $p<0.05$

Table 3: Anti-nociceptive effect of methanol extract of $M$. pumulis herb by tail flick method in mice

\begin{tabular}{|c|c|c|c|c|c|c|c|c|c|c|}
\hline Treatment & $\begin{array}{l}\text { Dose } \\
\mathrm{mg} / \mathrm{kg}\end{array}$ & $\mathbf{O h}$ & $0.5 \mathrm{~h}$ & $1 \mathrm{~h}$ & $1.5 \mathrm{~h}$ & $2 \mathrm{~h}$ & $2.5 \mathrm{~h}$ & $3 \mathrm{~h}$ & $3.5 \mathrm{~h}$ & $4 \mathrm{~h}$ \\
\hline \multirow[t]{3}{*}{$\overline{\mathrm{DMSO}}$} & $10 \mathrm{ml}$ & $1.46 \pm 0.30$ & $1.65 \pm 0.36$ & $2.03 \pm 0.32$ & $2.40 \pm 0.43$ & $2.74 \pm 0.37$ & $2.51 \pm 0.30$ & $2.50 \pm 0.18$ & $1.60 \pm 0.27$ & $1.52 \pm 0.28$ \\
\hline & 150 & 0.17 & 80 & 23.7 & $25.4^{*}$ & 35.8 & 33.7 & $26.38^{*} \pm 2.80$ & $22.12 \pm 2.44$ & $60.88^{*} \pm 4.73$ \\
\hline & 30 & $1.23^{*} \pm 0.29$ & $21.22 \pm 2.32$ & $22.08 \pm 2.03$ & 15 & $2 \pm 1.65$ & 3.14 & $9.49 \pm 1.18$ & $11.08^{*} \pm 1.28$ & $7.28^{*} \pm 1.06$ \\
\hline & 600 & $0.99 \pm 0.20$ & $3.30^{*} \pm 0.82$ & $23.66^{*} \pm 2.60$ & $25.24 \pm 2.68$ & $37.50 \pm 3.06$ & $48.40^{*} \pm 3.86$ & $27.85 \pm 2.79$ & $21.99 \pm 2.46$ & $111.0^{*} \pm 3.62$ \\
\hline iclof & 50 & $1.28^{*} \pm 0.327$ & $15.25^{\star} \pm 2.078$ & $3.21 \pm 0.704$ & $2.58 \pm 0.442$ & $2.73 \pm 0.386$ & $2.69 \pm 0.501$ & $2.70 \pm 0.300$ & $3.05 \pm 0.540$ & $1.76 \pm 0.343$ \\
\hline
\end{tabular}

Results are presented in seconds and values are expressed as mean \pm SEM $(n=5)$. The data was analyzed by one way ANOVA followed by Tukey's test using SPSS. All the treatments at different time intervals were compared with their matching time interval of the control group; * $p<0.05$ 
Table 4: Analgesic effect of methanolic extract of $M$. pumilus by acetic acid-induced writhing in mice

\begin{tabular}{|c|c|c|c|}
\hline Treatment & $\begin{array}{l}\text { Dose } \\
\text { (mg/kg/ } \\
\text { day) }\end{array}$ & $\begin{array}{c}\text { Number of } \\
\text { writhes }\end{array}$ & $\begin{array}{c}\text { Protection } \\
(\%)\end{array}$ \\
\hline $\begin{array}{l}\text { Control } \\
\text { (DMSO) }\end{array}$ & $\begin{array}{l}10 \mathrm{~mL} / \mathrm{kg}+ \\
0.6 \% \\
\text { acetic acid }\end{array}$ & $45.00 \pm 0.66$ & 0 \\
\hline Extract & $\begin{array}{l}150 \\
300 \\
600\end{array}$ & $\begin{array}{l}37.38 \pm 0.37^{*} \\
27.02 \pm 0.65^{\star} \\
18.38 \pm 0.64^{*}\end{array}$ & $\begin{array}{l}16.93 \\
39.96 \\
59.16\end{array}$ \\
\hline $\begin{array}{l}\text { Diclofenac } \\
\mathrm{Na}\end{array}$ & 50 & $08.60 \pm 0.52^{*}$ & 80.89 \\
\hline \multicolumn{4}{|c|}{$\begin{array}{l}\text { The number of writhes are presented in seconds and } \\
\text { values are expressed as mean } \pm \text { SEM }(\mathrm{n}=5) \text {. The data } \\
\text { was analyzed by one way ANOVA followed by Tukey's } \\
\text { test using SPSS. All the treatments at different time } \\
\text { intervals were compared with their matching time } \\
\text { interval of the control group; }{ }^{\star} p<0.05\end{array}$} \\
\hline
\end{tabular}

maintained all along the experiment with a maximum effect $5.42 \mathrm{~mm} \pm 0.26$. The extract ( 150 and $300 \mathrm{mg} / \mathrm{kg}$ ) induced significant $(p<0.05)$ anti-inflammatory effect and the antiinflammatory effect of diclofenac sodium (50 $\mathrm{mg} / \mathrm{kg}$ ) was comparable with that of the extract (Table 5).

\section{Hepatoprotective activity}

The hepatoprotective activity of $M$. pumilus treated group (group 4) showed significant $p<$ 0.05 reduction in liver enzymes i.e. ALT, AST, ALP, total protein and total bilirubin levels when compared with Group 2 INH $(50 \mathrm{mg} / \mathrm{kg})+$ RMP $(100 \mathrm{mg} / \mathrm{kg})$. Significant $(p<0.05)$ results were also obtained with silymarin but more pronounced hepatoprotective effect was observed with the methanol extract (Figure 1).

\section{Histopathological features}

Histopathological examination also showed less damage to the hepatocytes and liver architecture in methanol extract- and silymarin-treated groups when compared with isoniazid $(50 \mathrm{mg} / \mathrm{kg}$ and rifampicin (100 mg/kg) treated group (Figure 2).

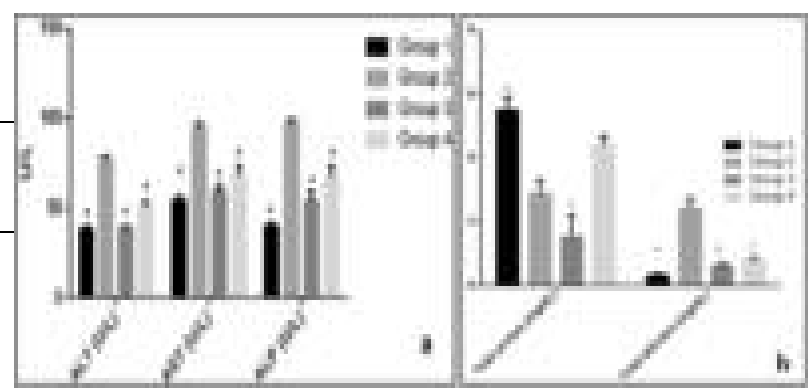

Figure 1: Comparison of the alterations in the liver markers by methanol extract of $M$. pumilus and silymarin treatments with isoniazid and rifampicin induced hepatotoxic treatment. Group $1=$ Control group; Group 2= INH (50 mg/kg) + RMP (100 mg/kg); Group 3 = extract of silymarin $(100 \mathrm{mg} / \mathrm{kg})$, INH (50 $\mathrm{mg} / \mathrm{kg}$ ) and RMP (100 mg/kg); Group 4 = extract of $M$. pumilus (400 mg/kg), INH (50 mg/kg) and RMP (100 $\mathrm{mg} / \mathrm{kg}$ ). All groups are compared with Group 2 using Graphpad Prizm by applying One-way ANOVA. * represents $p<0.05$. a: Levels of ALT, AST, and ALP, b: Levels of total protein and total bilirubin

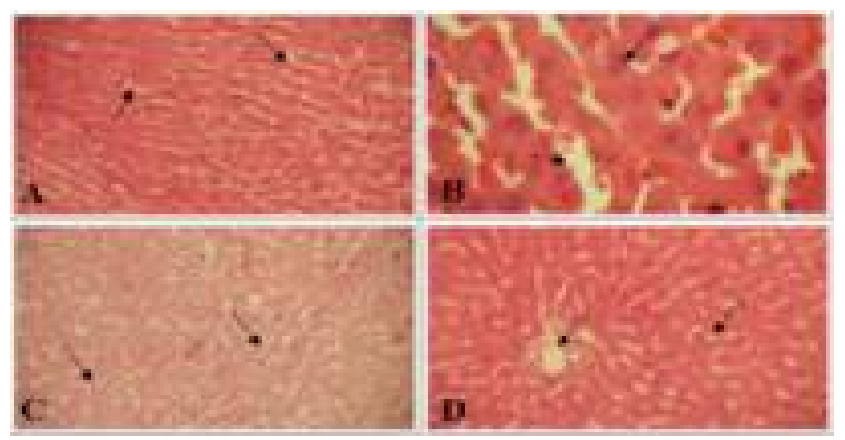

Figure 2: A: Normal group; normal hepatocytes, B: Toxic group; hepatocyte degeneration, C: Standard group; hepatocyte regeneration, D: Experimental group; mild hepatocyte regeneration

\section{DISCUSSION}

Pain and inflammation are connected with numerous pathological conditions. Synthetic drugs accessible for curing these disorders cause numerous undesirable effects. A number of studies are being conducted worldwide to assess natural sources for the active or lead

Table 5: Anti-inflammatory effect of $\mathrm{MeOH}$ extract of $M$. pumilus by carrageenan-induced rat paw edema method

\begin{tabular}{|c|c|c|c|c|c|c|c|}
\hline Treatment & $\begin{array}{c}\text { Dose } \\
\text { (mg/kg/day) }\end{array}$ & $\mathbf{O h}$ & $0.5 \mathrm{~h}$ & $1 \mathrm{~h}$ & $2 \mathrm{~h}$ & $3 \mathrm{~h}$ & $4 \mathrm{~h}$ \\
\hline DMSO & $10 \mathrm{~mL}$ & $5.15 \pm 0.11$ & $6.62 \pm 0.20$ & $7.56 \pm 0.12$ & $7.12 \pm 0.11$ & $7.00 \pm 0.14$ & $6.72 \pm 0.13$ \\
\hline \multirow[t]{3}{*}{ Extract } & 150 & $4.18 \pm 0.26$ & $4.95^{\star} \pm 0.21$ & $5.13^{*} \pm 0.22$ & $4.66^{*} \pm 0.24$ & $4.71^{*} \pm 0.28$ & $4.42^{*} \pm 0.25$ \\
\hline & 300 & $4.91 \pm 0.34$ & $5.54^{*} \pm 0.28$ & $6.12^{*} \pm 0.25$ & $5.90^{*} \pm 0.19$ & $5.84^{*} \pm 0.22$ & $5.42^{*} \pm 0.26$ \\
\hline & 600 & $5.13 \pm 0.29$ & $5.95 \pm 0.41$ & $6.10^{*} \pm 0.46$ & $6.20 \pm 0.43$ & $5.90^{*} \pm 0.41$ & $5.44^{\star} \pm 0.41$ \\
\hline Diclofenac $\mathrm{Na}$ & 50 & $4.95 \pm 0.26$ & $5.84 \pm 0.22$ & $6.04^{\star} \pm 0.23$ & $5.96^{\star} \pm 0.28$ & $5.74^{*} \pm 0.24$ & $5.40 * \pm 0.23$ \\
\hline
\end{tabular}

All the results are presented in mm and values are expressed as mean \pm SEM $(n=5)$. The data was analyzed by one way ANOVA followed by Tukey's test using SPSS. All the treatments at different time intervals were compared with their matching time interval of the DMSO-treated group; ${ }^{*} p<0.05$ 
compounds with best safety profiles [15]. Medicinal plants are accepted as a vital source of new compounds having therapeutic potential. The research on folkloric usage of plants as pain relievers, anti-inflammatory and hepatoprotective agents should therefore be viewed as a fruitful research strategy for search of a new analgesic, anti-inflammatory and hepatoprotective drugs [18].

The results of the analgesic experiments showed that $M$. pumilus exhibits both peripheral and central analgesic properties. Tail immersion and hot plate test are suitable methods for the assessment of centrally acting analgesic drugs while acetic acid-induced writhing is used for the evaluation of peripherally acting drugs. $M$. pumilus extract also showed significant $(p<$ 0.05 ) analgesic effect in both the hot plate and tail immersion tests. The extract showed maximum analgesic effect after $1 \mathrm{~h}$ of administration and prevailed for up to $4 \mathrm{~h}$ with all doses $(150,300$ and $600 \mathrm{mg} / \mathrm{kg}$ ) in hot plate experiment. Hot plate method is the oldest method employed to study the supra spinal analgesic effect of the drugs. Hence it could be suggested that the plant extract might possess central supra spinal analgesic activity. The tail immersion test is thought to be particular to analyze compounds acting through opioid receptor [18]. The plant extract expanded pain threshold basal latency time demonstrating that it might act by means of centrally mediated analgesic mechanism.

The extract of Mazus pumilus exhibited significant $(p<0.05)$ dose dependent inhibition of acetic acid-induced writhing in mice, comparable to Diclofenac Na. Writhing is a noticeable response produced due to the intense pain produced by acetic acid. Acetic acid-induced writhing model shows pain sensation by activating localized inflammatory response. The pain stimulus results into release of free arachidonic acid from the tissue phospholipid. The acetic acid induced writhing response is an accurate method to assess peripherally acting analgesics. The response is thought to be intervened by peritoneal mast cells, acid sensing ion channels, and the prostaglandin pathways [18]. The analgesic effect of the extract might be due to the inhibition of arachidonic acid pathways involving cyclooxygenase enzyme. A dose dependent increase in the analgesic effect of the extract was observed. The number of the writhes decreased more significantly $(p<0.05)$, with increasing dose. The inhibitory effect might be due to the different peripheral mechanisms of pain inhibition. The flavonoids present in the extract might be responsible for the analgesic action due to interference with the prostaglandin studies and inhibition of prostaglandin synthase as have been observed in previous studies [19].

Carrageenan-induced paw edema is one of the most commonly employed animal model to evaluate the anti-inflammatory effect of natural products as well as synthetic chemical compounds. Carrageenan induces edema in paw in biphasic manner for the $1-4 \mathrm{~h}$; the early phase $(1$ or $1.5 \mathrm{~h})$ is predominately a nonphagocytic edema and is associated with the release of autacoids. The second phase $(2-4 \mathrm{~h})$ consist of expanded edema formation that stayed up to $4 \mathrm{~h}$. The early phase has been induced due to the action of mediators such as histamine, serotonin and bradykinin on vascular permeability. Over-production of prostaglandins might be the reason for the appearance of second phase [14,18]. Since the extract significantly inhibited paw edema induced by carrageenan in the second phase, this finding suggests possible inhibition of COX synthesis by the extract and this impact is similar to that produced by non-steroidal anti-inflammatory drugs whose mechanism of action is inhibition of the COX enzyme [19]. In carrageenan paw edema model of acute inflammation, extract significantly reduce the paw size at $1 \mathrm{st}$, 3rd and 4th $\mathrm{h}$ comparable with diclofenac sodium. The herb extract showed significant dose dependent reduction in paw size. This may be because of the inhibition of the biphasic response induced by the carrageenan. The anti-inflammatory effect might be attributed to the presence of terpenes, saponins, glycosides and flavonoids [20].

It is conceivable that multiple mechanisms like inhibition of either cyclooxygenase and/or lipooxygenase enzyme or inhibition of synthesis, release and action of above inflammatory mediators may be involved in acute antiinflammatory effect of extract. In previous studies, several plants showing anti-inflammatory effects have been proposed to act through these mechanisms. [21,22].

The phytochemical screening of Mazus pumilus plant extract uncovered the existence of the various phytochemicals (Table 1). The present investigation proves the analgesic and antiinflammatory action of the plant extract in experimental animals however the exact mechanisms still requires further evaluations [15]. These activities might be because of its high flavonoid substance which are responsible for free radical scavenging activity, as these free radicals are the cause of pain stimulation, and antioxidants demonstrated decrease in such pain [23]. A number of plants extract demonstrated 
analgesic and anti-inflammatory impact on animals and their impacts have been ascribed to the existence of triterpenoids, alkaloids, glycosides, flavonoids, tannins, saponins and sterols [24,25].

The hepatoprotective effect of the plant extract against INH and RMP induced liver damage might be attributed to the presence of the flavonoids and triterpenoids that have the property to scavenge the free radicals that are responsible to decrease the levels of glutathione and related thiols [26]. The significant $(p<0.05)$ decrease in the biochemical markers of the liver is presented in Figure 1 and histopathological analysis of the liver treated with extract and silymarin (Figure 2) indicate the improvement in the antioxidant status of the liver.

\section{CONCLUSION}

The anti-nociceptive, anti-inflammatory and hepatoprotective effects of the methanol extract of $M$. pumilus may be due to the presence of secondary metabolites like glycosides, saponins, flavonoids and terpenoids. The mechanisms probably involve both the central and peripheral actions that inhibit the release and synthesis of prostaglandins and cyclooxygenase or blocking of nociceptors, while the hepatoprotective effect might have been caused by the antioxidant activity of the plant extract. However, further pharmacological and phytochemical analysis is required to determine the exact mechanisms and chemical constituents responsible for these actions.

\section{DECLARATIONS}

\section{Acknowledgement}

The project was funded by the Punjab University College of Pharmacy, University of the Punjab, Lahore, Pakistan.

\section{Conflict of interest}

No conflict of interest is associated with this work.

\section{Contribution of authors}

We declare that this work was done by the authors named in this article and all liabilities pertaining to claims relating to the content of this article will be borne by the authors. SI, Al and NI conceived and designed the study. UH and UN helped in plant material collection. SI, SHK and MSKA collected and analyzed the data. Al and
$\mathrm{NI}$ wrote the manuscript. All the authors read and approved the final manuscript.

\section{Open Access}

This is an Open Access article that uses a funding model which does not charge readers or their institutions for access and distributed under the terms of the Creative Commons Attribution License (http://creativecommons.org/licenses/by/ 4.0) and the Budapest Open Access Initiative (http://www.budapestopenaccessinitiative.org/rea d), which permit unrestricted use, distribution, and reproduction in any medium, provided the original work is properly credited.

\section{REFERENCES}

1. Müller $S D$, Florentino $D$, Ortmann $C F$, Martins $F A$, Danielski LG, Michels M, de Souza Constantino L, Petronilho F. Reginatto FH. Anti-inflammatory and antioxidant activities of aqueous extract of Cecropia glaziovii leaves. J Ethnopharmacol 2016; 185: 255-262.

2. van Andel T, Carvalheiro LG. Why urban citizens in developing countries use traditional medicines: the case of Suriname. Evid Based Complement Altern Med 2013; 2013.

3. Dey $Y N$, Ota $S$, Srikanth $N$, Jamal $M$, Wanjari M. A phytopharmacological review on an important medicinal plant-Amorphophallus paeoniifolius. Int quart J Res Ayur 2012; 33: 27-32.

4. Japanese Mazus: California Academy of science, US. [cited 2017 May 10]. Available from: http://www.inaturalist.org/taxa/126377-Mazus

5. Sharma J, Gairola S, Gaur RD, Painuli RM, Siddiqi TO. Ethnomedicinal plants used for treating epilepsy by indigenous communities of sub-Himalayan region of Uttarakhand, India. J Ethnopharmacol 2013; 150(1): 353-370.

6. Safdar N, Batool S, Tufail S, Masood N, Zehra R, Yasmin A. Antibacterial evaluation of three widespread weeds Mazus japonicus, Fumaria indica and Vicia faba from Pakistan. Res Pharm 2015; 5: 1-12.

7. Priya PV, Rao AS. Evaluation of Anticancer Activity of Mazus pumilus Leaf Extracts on Selected Human Cancerous Cell Lines. Int J Pharm Sci Rev Res 2016; 37: 185-189.

8. Ishtiaq S, Hanif U, Afridi MSK. Mazus pumilus (Burm. f.) Steenis; Pharmacognosy. Indian J Tradit Knowledge 2018; 17(1): 106-112.

9. Shahid $S$, Riaz $T$, Abbasi MA, Khalid $F$. In vitro assessment of protection from oxidative stress by various fractions of Mazus pumilus. J Chem Soc Pak 2013; 35: 594-599.

10. National Institutes of Health. Guide for the care and use of laboratory animals. 1985.

11. Aslam I, Afridi MSK. Pharmacognostic characterization of Beaumontia grandiflora (Roxb.) Wall. leaf for taxonomic

Trop J Pharm Res, April 2019; 18(4): 806 
identification for quality control of a drug. J App Res Med Aromatic Plants 2017.

12. Atta A, Alkofahi A. Anti-nociceptive and anti-inflammatory effects of some Jordanian medicinal plant extracts. J Ethnopharmacol 1998; 60: 117-124.

13. Hasan SR, Hossain MM, Akter R, Jamila M, Mazumder MEH, Alam MA, Faruque A, Rana S, Rahman $S$. Analgesic activity of the different fractions of the aerial parts of Commelina benghalensis Linn. IJP-Int $J$ Pharmacol 2010; 6(1): 63-67.

14. Perianayagam JB, Sharma SK, Joseph A, Christina AJM. Evaluation of anti-pyretic and analgesic activity of Emblica officinalis Gaertn. J Ethnopharmacol 2004; 95(1): 83-85.

15. Ishtiaq S, Ali T, Ahmad B, Anwar F, Afridi MSK, Shaheen H. Phytochemical and biological evaluations of methanolic extract of Amaranthus graecizans subsp. silvestris (Vill.) Brenan, British J Pharm Res 2017; 15(3): 1-11.

16. Ishtiaq S, Afridi MSK, Masood N. Amelioration of isoniazid and rifampicin-induced liver toxicity by Amaranthus graecizans subsp. silvestris in rat. Bangladesh J Pharmacol 2017; 12: 354-358.

17. Ishtiaq S, Akram M, Kamran SH, Hanif U, Afridi MSK, Rehman S, Afzal A, Asif A, Younus M, Akbar S. Acute and sub-acute toxicity study of a Pakistani polyherbal formulation, BMC Complement Altern Med 2017; 17: 387.

18. Kaushik D, Kumar A, Kaushik P, Rana A. Analgesic and Anti-Inflammatory Activity of Pinus roxburghii Sarg. Adv Pharmacol Sci 2012; 2012.

19. Dongmo A, Kamanyi A, Anchang M, Nkeh BC-A, Njamen $D$, Nguelefack $T$, Nole $T$, Wagner $H$. Anti-inflammatory and analgesic properties of the stem bark extracts of Erythrophleum suaveolens (Caesalpiniaceae), Guillemin \& Perrottet. J Ethnopharmacol 2001; 77: 137-141.

20. Paviaya US, Kumar P, Wanjari MM, Thenmozhi S, Balakrishnan B. Analgesic and anti-inflammatory activity of root bark of Grewia asiatica Linn. in rodents. Anc Sci Life 2013; 32: 150.

21. Tasleem F, Azhar I, Ali SN, Perveen S, Mahmood ZA. Analgesic and anti-inflammatory activities of Piper nigrum L. Asian Pac J Trop Med 2014; 7: S461-S468.

22. Shahid S, Riaz T, Abbasi MA, Khalid F. In vitro assessment of protection from oxidative stress by various fractions of Mazus pumilus. J Chem Soc Pak 2013; 35: 594-599.

23. Chakraborty ARKB, Devi RK, Rita S, Sharatchandra KH, Singh $\mathrm{Tl}$. Preliminary studies on anti-inflammatory and analgesic activities of Spilanthes acmella in experimental animal models. Indian J Pharmacol 2004; 36(3): 148-150.

24. Eldahshan OA, Abdel-Daim MM. Phytochemical study, cytotoxic, analgesic, antipyretic and anti-inflammatory activities of Strychnos nuxvomica. Cytotech 2015; 67(5): 831-844.

25. Ishtiaq S, Ahmad M, Hanif U, Akbar S, Kamran SH. Phytochemical and in vitro antioxidant evaluation of different fractions of Amaranthus graecizans subsp. silvestris (Vill.) Brenan. Asian Pacific J Trop Med 2014; 7: S342-S347.

26. Saleem U, Ahmad B, Hussain K, Ahmad M, Bukhari NI, Ishtiaq S. Estimation of antioxidant power in various extracts of Euphorbia helioscopia L. with five different in vitro antioxidant models. Asian J Chem 2014; 26(4): 1241. 